\title{
A NEW SPECIES OF MICRANTHEUM (EUPHORBIACEAE) FROM TASMANIA
}

\author{
by A.E. Orchard
}

(with three text-figures)

\begin{abstract}
A second Tasmanian species of Micrantheum, $M$. serpentinum, is described from western Tasmania. The new taxon is apparently confined to three small outcrops of serpentine rock. It is closely allied to the more widespread $M$. hexandrum, and both species are fully described and illustrated. A key is provided to all four species in the genus.
\end{abstract}

Key Words: Euphorbiaceae, Micrantheum, taxonomy, Tasmania, Australia.

In BANKS, M.R. et al. (Eds), 1991 (31:iii): ASPECTS OF TASMANIAN BOTANY - A TRIBUTE TO WINIFRED CURTIS.

Roy. Soc. Tasm. Hobart: 59-64. https://doi.org/10.26749/rstpp.124.2.59

\section{INTRODUCTION}

Micrantheum is a genus of four species of shrubs or subshrubs, confined to eastern and southeastern Australia. They typically form a minor component of the understorey of drier woodlands, or occur on rocky outcrops or in heathlands. The genus is characterised by having leaves in alternately arranged groups of three (sometimes 2-5), in lacking petals (but with a petaloid calyx), in having a vestigial ovary in the male flowers, undivided styles and a 2-3 locular ovary in the female flowers, and two ovules in each locule. With the other small genera Pseudanthus and Stachystemon it makes up the tribe Caletieae, one of the smallest subdivisions of the family Euphorbiaceae.

\section{TAXONOMIC HISTORY}

Micrantheum was described by Desfontaines (1818) with a single species, $M$. ericoides. A second species, M. hexandrum, was described by J.D. Hooker (1847), differing from $M$. ericoides principally in having six (rarely up to nine) stamens in the male flowers, rather than three. The third species, $M$. demissum, endemic to South Australia, was described by Ferdinand von Mueller (1890). It was distinguished from the other two species by its fewer floral parts (calyx segments and stamens usually four instead of six, ovary twocelled instead of three). Recently a fourth species, related to $M$. hexandrum, has been found on serpentine outcrops in western Tasmania, and is described below.

Although these four species form an apparently welldefined group, geographically and in terms of their semi-whorled leaves, they have been placed in segregate genera at various times on the basis of differences in numbers of floral parts. Thus Baillon (1858) described the genus Caletia to accommodate $M$. hexandrum (which he renamed $C$. micrantheoides), distinguished from Micrantheum s. str. (= M. ericoides) by its larger number of stamens. Similarly, Ewart (in Ewart et al. 1909) described a new genus Allenia, comprising only $M$. demissum (renamed $A$. blackiana) because the flowers were found to have their parts in twos or fours instead of threes or sixes.

\section{KEY TO THE SPECIES OF MICRANTHEUM}

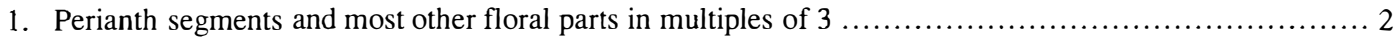

1. Perianth segments and most other floral parts in multiples of $2 \ldots \ldots \ldots \ldots \ldots \ldots \ldots \ldots \ldots$. $\ldots$. demissum

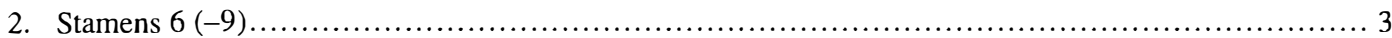

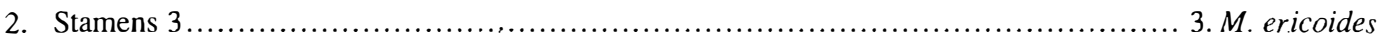

3. Leaves obtuse, minutely scabrous on margins near the tip; flowers in fascicles of $1(-2)$, the male flowers on pedicels to $1.7 \mathrm{~mm}$ long; fruits $<3.5 \mathrm{~mm}$ long, seeds $2-2.1 \mathrm{~mm}$ long .................. 1. M. serpentinum

3. Leaves acute, glabrous; flowers in fascicles of (1)-3, the male flowers on pedicels to $7 \mathrm{~mm}$ long; fruits $>5 \mathrm{~mm}$ long, seeds $3.5-4 \mathrm{~mm}$ long 

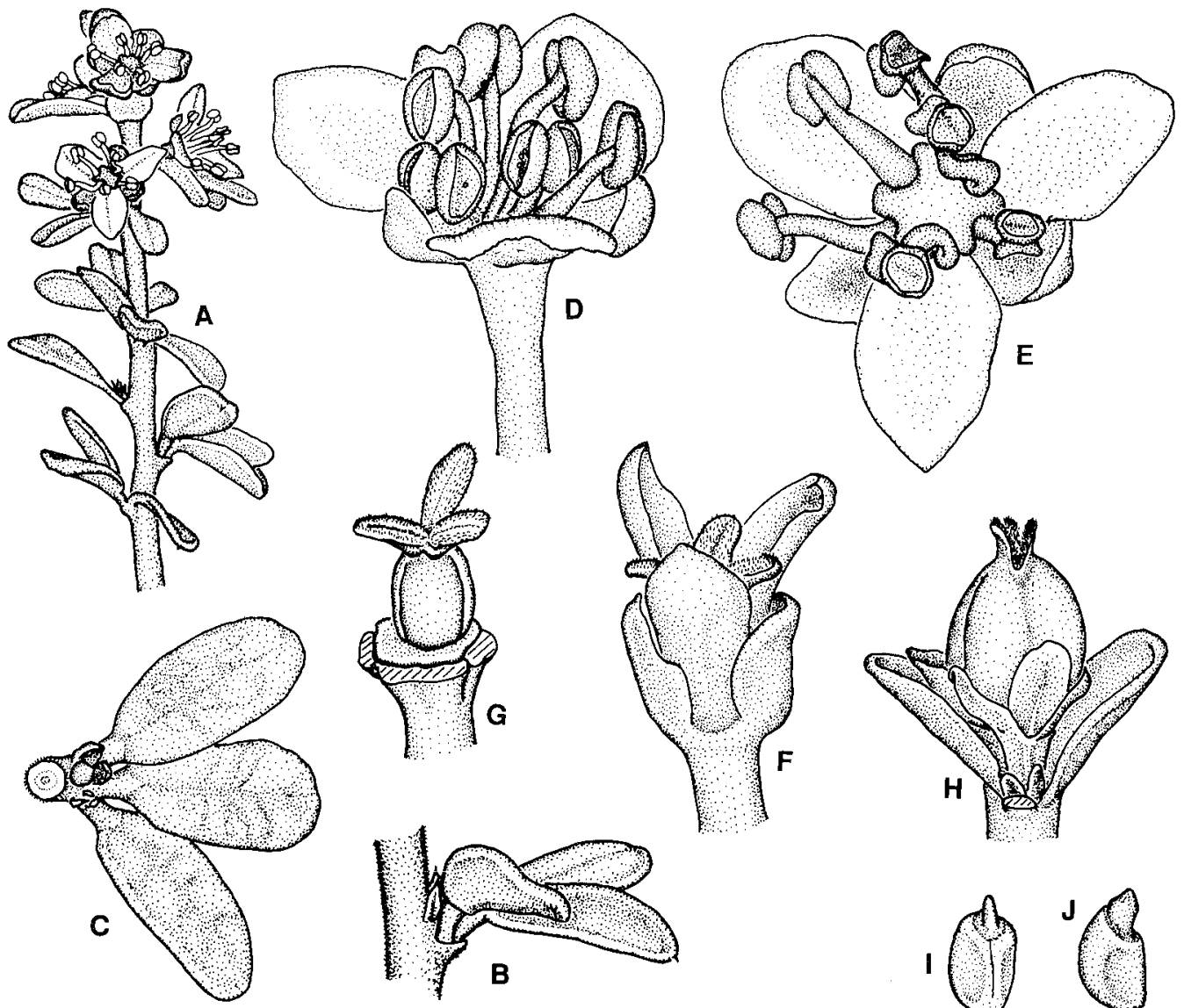

FIG. 1 - Micrantheum serpentinum: (A) flowering branch with male flowers, (B) group of three leaves at a mode, $(C)$ the same, from above, $(D)$ male flower, $(E)$ the same, from above showing the vestigial ovary, $(F)$ female flower, $(G)$ the same with perianth removed, $(H)$ fruit, $(I \& J)$ seed. Scales represent $1 \mathrm{~mm} .[A-G$ from M.J. Brown s.n. (HO 116238), H-J from S.J. Jarman s.n. (HO 116240)]

Grüning (1958) treated the above three taxa as each comprising a monotypic subgenus of Micrantheum. He considered that the differences between them were insufficient for generic rank. All other recent authors, including Hutchinson (1969), concur with this, and all three taxa are treated as species of Micrantheum in modern works.

\section{Micrantheum serpentinum Orchard, sp. nov.}

Suffrutex usque ad $1 \mathrm{~m}$ altum; ramunculi dense scabri, pilis unicellularibus $0.1 \mathrm{~mm}$ longis. Folia in fasciculis trium, alternis, petiolo $0.5 \mathrm{~mm}$ longo, lamina oblonga vel anguste ovata vel anguste obovata, (3-)5-9 mm longa, $1.5-3.3 \mathrm{~mm}$ lata, integra, glabra praeter pilos sparsos minute in margine prope apicem; apice rotundato et plerumque minute apiculato vel perpaulum emarginato. Flores solitarii (rare binati) in axillis foliorum superorum. Flores masculi in pedicellis $1.0-1.7 \mathrm{~mm}$ longis; tepala interiora c. $1.7 \mathrm{~mm}$ longa marginibus integris; stamina 6 . Flores feminei in pedicellis c. $0.5 \mathrm{~mm}$ longis; ovarium 3-loculare unusquisque ovulis 2. Fructus in pedicello c. $0.8 \mathrm{~mm}$ longo, ovoideus, $3-3.3 \mathrm{~mm}$ longus, $2.3-2.7 \mathrm{~mm}$ in diametro. Semina ochracea, nitida, oblonga vel suborbicularia, $2.0-2.1 \mathrm{~mm}$ longa, $1.3-1.4(-1.7) \mathrm{mm}$ in diametris.

\section{Typus}

Tasmania: West Coast - Serpentine Hill, c. $5 \mathrm{~km} \mathrm{SSW}$ of Renison Bell, on Murchison Highway, S.J. Jarman 
\& G. Kantvilas s.n., 6.x.1989. Holotypus: HO 119291. Isotypi: AD, BRI, CANB, CBG, DNA, MEL, NSW, PERTH.

\section{Description}

Subshrub 1-2 m tall; stems ascending, straggly, freely branching; older branches with dark-grey to black rough or ridged bark; young twigs silvery-grey to purplish, with indumentum of dense spreading unicellular hairs $0.1 \mathrm{~mm}$ long. Leaves oblong or narrowly ovate or narrowly obovate, in groups of 3 at alternately arranged nodes; petioles pale, $0.2-0.5 \mathrm{~mm}$ long; lamina (3-)5-9 mm long, 1.5-3.3 mm wide, glabrous except for sparse minute hairs on margin mainly near the tip and sometimes on the midrib below, dark subglossy green concave and very slightly rugulose above, paler with midrib \pm obscure below, tip rounded and usually minutely apiculate or very minutely notched. Flowers solitary (rarely paired) in axils of upper leaves. Plants monoecious, the male flowers usually above the females and slightly outnumbering them; flowers subtended by short thick deltoid dark reddish-brown scales. Male flowers on pedicels $1.0-1.7 \mathrm{~mm}$ long; outer tepals 3 , yellow, flushed red in parts, strongly hooded, ovate, $1.3 \mathrm{~mm}$ long; inner tepals 3 , larger, yellow with a red flush, flat with margins reflexed, \pm orbicular, c. $1.7 \mathrm{~mm}$ long; stamens 6 , filaments c. $1.3 \mathrm{~mm}$ long, anthers yellow, dorsifixed, c. $0.6 \mathrm{~mm}$ long; ovary vestigial, reduced to a green 3-lobed disc, each lobe notched at tip. Female flowers on pedicels c. $0.5 \mathrm{~mm}$ long; outer tepals 3 , thick, greenish yellow with reddish tips, slightly hooded at acute tip, c. $1.7 \mathrm{~mm}$ long; inner tepals 3 , greenish yellow, oblong with a rounded tip, c. $2.5 \mathrm{~mm}$ long, erect with spreading tips; ovary seated on a slightly undulate disc, green, glabrous, slightly 3-lobed, c. $1 \mathrm{~mm}$ long, 3 locular with 2 ovules in each locule; styles 3 , flattened, reddish on bullate adaxial stigmatic surfaces. Fruit on a pedicel c. $0.8 \mathrm{~mm}$ long, cupped by the persistent perianth; fruit ovoid, $3-3.3 \mathrm{~mm}$ long (excluding thick persistent purplish-black styles c. $0.8 \mathrm{~mm}$ long), $2.3-2.7 \mathrm{~mm}$ in diameter, bluntly 3-lobed, slightly rugose, subglossy, yellowish brown, splitting at maturity into 6 segments leaving a persistent columella. Seeds pale creamy brown, glossy, oblong to suborbicular, $2.0-2.1 \mathrm{~mm}$ long, $1.3-1.4(-1.7) \mathrm{mm}$ in diameter, with a short cream caruncle (fig. 1).

\section{Distribution}

Confined to Tasmania, where it is known from only three localities: Serpentine Hill and Serpentine Ridge, both near Renison Bell, and a tributary of the Heazlewood River between Luina and Savage River, all in the West Coast region (Orchard 1988) of Tasmania (fig. 2).

\section{Ecology}

Found in rocky hillside shrubberies, often (possibly always) on serpentine rocks, at altitudes of $200-300 \mathrm{~m}$. Flowers are present from September to November, and fruits mature in January. Unlike $M$. hexandrum, where some plants bear male flowers only, $M$. serpentinum is strictly monoecious, with no sign of bisexual flowers or female flowers with staminodes. In addition the male flower/female flower ratio is much nearer $1: 1$ than in $M$. hexandrum, where male flowers far outnumber females in the population.

\section{Specimens Examined}

Tasmania: West Coast - M.J. Brown s.n. (HO 116234); M.J. Brown s.n. (HO 116238); M.J. Brown s.n. (AD, HO 116239, MEL); M.J. Brown s.n. (HO 116237, NSW); R. Burns ANBG 1936 (HO); T.E. Burns s.n. (HO 114425, MEL, NSW); H.F. Comber 2182 (HO); A.M. Gray G 613 (HO); S.J. Jarman s.n. (AD, BRI, HO 116240, MEL); S.J. Jarman \& G. Kantvilas s.n. (AD, BRI, HO 116235-6, MEL); S.J. Jarman \& G. Kantvilas s.n. (HO 119322-6); A. Plumridge s.n. (HO 114424) [Further details of specimens listed in this paper, e.g. collecting site and date, are available from the Herbaria noted or from the Royal Society of Tasmania Library (Archives), GPO Box 1166M, Hobart, Tasmania, Australia 7001. Ed.]

\section{Conservation Status}

Locally abundant but very restricted by its substrate requirements. No populations occur within existing

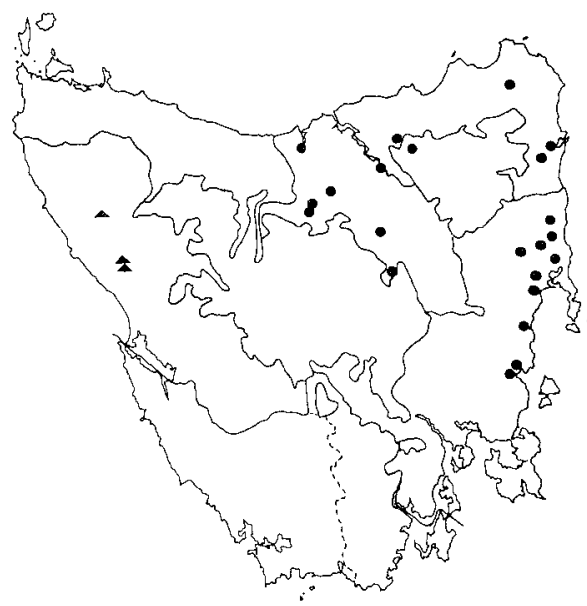

FIG. 2 - Distribution of Micrantheum in Tasmania. Regional boundaries as in Orchard (1988).

$\mathbf{\Delta}=$ M. serpentinum, $\bullet=$ M. hexandrum. 
reserves. For these two reasons, the species must be considered vulnerable, although there are no immediately apparent threats to any of the populations (apart perhaps from road-widening activities).

\section{Comments}

This species is clearly closely related to $M$. hexandrum, differing from it in leaf shape and by having most parts smaller. As well as these quantitative differences there are also qualitative ones - the usually minutely fringed petals of the male flowers of $M$. hexandrum vs the entire petals of $M$. serpentinum, the tiny hairs on the leaf margins of $M$. serpentinum which are absent in $M$. hexandrum, the differences in sex distribution, and the differences in seed shape and colour. The two species differ also in habitat preference. While $M$. hexandrum, within Tasmania where the two species coexist, is strictly riverine, $M$. serpentinum is confined to rocky hillsides in high rainfall areas, apparently only on serpentine substrates. All of these differences support the recognition of this taxon as a new species, endemic to Tasmania and of very restricted distribution. To facilitate comparison, a description of $M$. hexandrum, drawn almost entirely from Tasmanian material, follows.

\section{Micrantheum hexandrum J.D. Hooker}

Micrantheum hexandrum J.D. Hooker, Lond. J. Bot. 6 (1847) 283-4 (as "Micranthemum"). [Typus: "Launceston; Scott, Lawrence, Gunn". Syntypus: R.C. Gunn 35/1842, Launceston, HO 57423!]; J. Hooker, Fl. Tasm. 1 (1857) 341-2 ("Micranthea hexandra"); Bentham, Fl. Austral. 6 (1873) 57-58; Moore \& Betche, Handbk Fl. NSW (1893) 70; Pax, Nat. Pflanzenfam. III, 5 (1896) 113: Rodway, Tasm. Fl. (1903) 177; Grüning, Pflrch 58 (1958) 21-25; Curtis, Stud. Fl. Tasm. 3 (1967) 634; Beadle, Evans, Carolin \& Tindale, Fl. Syd. Reg. (1972) 248; Willis, Handbk PI. Vic. (1973) 351; Rotherham et al., Fl. P1. NSW \& S. Qld (1975) 73; Beadle, Stud. Fl. NE NSW 3 (1976) 306; Galbraith, Field Guide Wildfls SE Aust. (1977) 215; Jacobs \& Pickard, Pl. NSW (1981) 117; Stanley, in Stanley \& Ross, Fl. SE Qld 1 (1983) 426-7.

Caletia micrantheoides Baillon, Étude. Euph. (1858) 554 [Nom. illeg.: based on M. hexandrum]; Mueller Arg., Linnaea 34 (1865) 55.

Caletia hexandra (J.D. Hook.) Muell. Arg. in DC., Prod. 15 (1866) 194.

\section{Illustrations}

Pax, Nat. Pflanzenfam. III 5 (1896) 114, fig. 73C; Rotherham et al., Fl. Pl. NSW \& S Qld (1975) 73, fig. 207; Galbraith, Field Guide Wildlfls SE Aust. (1977) pl.73, fig. 3, 3a.

\section{Description}

Shrub to $3 \mathrm{~m}$ tall; stems erect, freely branching; older branches with dark-grey to black smooth or ridged bark; young twigs deep red-purple, with indumentum of moderately dense spreading unicellular hairs to $0.5 \mathrm{~mm}$ long. Leaves linear to very narrowly oblanceolate, in groups of 3 (rarely 4) at alternately arranged nodes; petiole $0.8 \mathrm{~mm}$ long; lamina (3-)6-16(-22) mm long, (1.0-) 1.5-2.0(-3.5) mm wide, glabrous, smooth and slightly concave above, midrib slightly prominent below, tip acute with a short, usually blunt apiculum. Flowers unisexual, 1-3 at each upper node. Plants androdioecious with some individuals bearing prolific male flowers, others with a mixture of fewer males plus some females, and in the latter the males are usually borne above the females. Male flowers on pedicels (2.5-)5-7 mm long; outer tepals 3 , creamy white, hooded, ovate, c. $1.4 \mathrm{~mm}$ long; inner tepals 3 , creamy white, flat, with margins reflexed and usuaily minutely fimbriate, obovate to orbicular, $2.0-2.1 \mathrm{~mm}$ long; stamens 6(-9), filaments $1.3-2.3 \mathrm{~mm}$ long, anthers reddish, dorsifixed, c. $0.7 \mathrm{~mm}$ long, opening by slits. Female flowers on pedicels $1-3 \mathrm{~mm}$ long; outer tepals 3 , creamy white, hooded, c. $2.9 \mathrm{~mm}$ long; inner tepals 3 , creamy white, narrowly ovate, c. $3.3 \mathrm{~mm}$ long, tip rounded; inner and outer tepals usually long-fimbriate on inner surface at the base; disc obscure; ovary green, glabrous, 3-lobed, c. $1 \mathrm{~mm}$ long, 3-locular with 2 ovules in each locule; styles 3 , flattened, greenish red on bullate adaxial stigmatic surfaces. Fruit on a pedicel $1-3 \mathrm{~mm}$ long; perianth and styles persistent; fruit ovoid, c. $7 \mathrm{~mm}$ long, $5.5-6 \mathrm{~mm}$ in diameter, very slightly 6-lobed, more or less smooth or with slightly raised veins, pale brown, glabrous, splitting at maturity into 6 segments, leaving a persistent columella. Seeds light reddish brown, glossy, cylindrical, $3.5-4 \mathrm{~mm}$ long, 1.3-1.5 mm in diameter, with a short cream caruncle (fig. 3).

\section{Distribution}

Extends from southeastern Queensland through the Tablelands and Central Coast of New South Wales and the mountains of eastern Victoria, to Tasmania (northern Midlands, North East and East Coast) (fig. 2). In Tasmania there is also an anomalous high altitude population on Mt Arthur in the Ben Lomond district (see below).

\section{Ecology}

Found in open or closed shrubberies in sclerophyll forests, usually in riverine habitats. In the northern part of its range $M$. hexandrum is usually a montane plant found at up to $700 \mathrm{~m}$. In Tasmania it descends to near sea level. Flowering takes place from September to November, and fruits persist from November to January. Although on most plants the flowers are strictly 

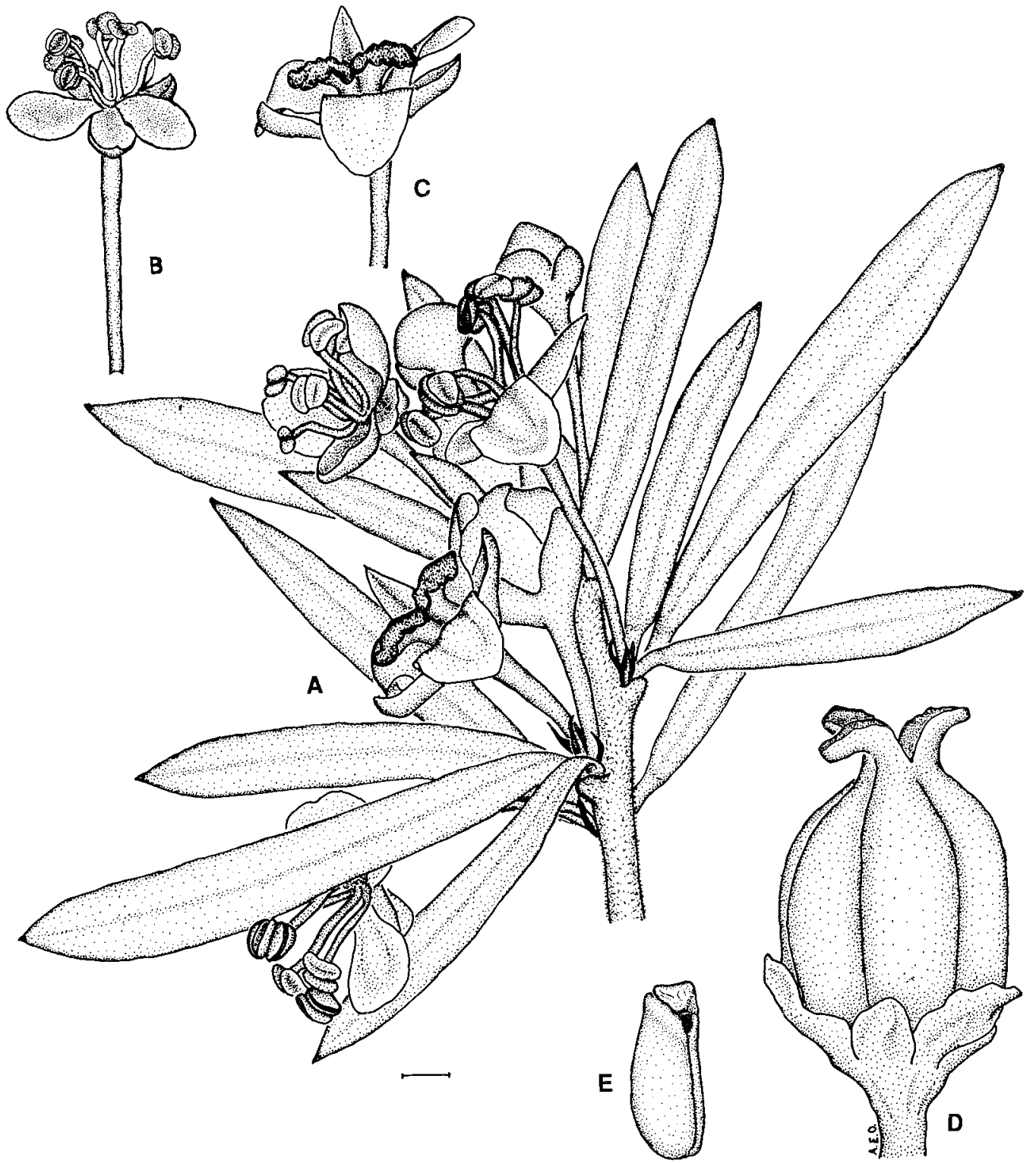

FIG. 3 - Micrantheum hexandrum: (A) flowering branch with male and female flowers, $(B)$ male flower, (C) female flower, (D) fruit, (E) seed. (Scale represents $1 \mathrm{~mm}$. A-C - from F. Hood 54 (HO); D-E-from J. Somerville s.n. (HO 63I7).) 
unisexual, occasionally (e.g. W.M. Curtis s.n., HO 114426) the female flowers bear a few (usually less than six) stamens, most of which seem to be staminodal in character.

\section{Specimens Examined (selection only)}

Victoria: R.J. Adair 1428 (HO).

Tasmania: Midlands - F. Burbury s.n. (HO 6319); J. Somerville s.n. (HO 6317); L. Rodway s.n. (HO 6326); North East - P. Collier 1474, 1475 (HO); A. Simson s.n. (HO 6320); East Coast - W.M. Curtis s.n. (HO 114468); W.M. Curtis s.n. (HO 114426); F. Hood 54 (HO). [Further details of specimens listed in this paper, e.g. collecting site and date, are available from the Herbaria noted or from the Royal Society of Tasmania Library (Archives), GPO Box 1166M, Hobart, Tasmania, Australia 7001.]

\section{Conservation Status}

Widespread in the eastern part of Tasmania, but confined to a specialised habitat (riverine shrubberies). This type of community is poorly reserved in Tasmania, and few populations of $M$. hexandrum are found within existing reserves.

\section{Comments}

While $M$. hexandrum within Tasmania is usually easily distinguished from $M$. serpentinum by its longer and proportionally much narrower leaves, there are a number of collections from near the summit of Mt Arthur and from Thompsons Marsh that are somewhat intermediate. The leaves of these anomalous plants are more or less ovate/obovate and often as short as 3-5 mm. Their flowers also tend to be slightly smaller than typical $M$. hexandrum. However, in their critical characters (fringed petals, shape and size of fruit and seed, hairs on leaf margins, general range of flower part sizes etc.) these alpine or subalpine plants belong in $M$. hexandrum rather than $M$. serpentinum. They will be the subject of a separate study by R.J.F. Henderson, to be reported elsewhere. In the meantime the description above encompasses their character states.
Accounts of $M$. hexandrum from mainland Australia mention that the number of stamens in the male flowers can sometimes be nine. All Tasmanian specimens examined in this study had only six stamens.

\section{ACKNOWLEDGEMENTS}

I am grateful to all those collectors who made special efforts to assemble representative specimens for this study. Particularly noteworthy in this respect were Drs Jean Jarman, Gintaras Kantvilas and Mick Brown, Mr Phil Collier and Mr Allan Gray. Rod Henderson kindly read a first draft of the manuscript and made many useful suggestions.

\section{REFERENCES}

BAILLON, H.E., 1858: ÉTUDE GÉNÉRALE DU GROUPE DES EUPHORBIACÉES. Victor Masson, Paris.

DesfontaInes, R.L., 1818: Description de quatre noveaux genres des plantes. Mem. Mus. Hist. Nat. Paris 4: 245-255.

Ewart, A.J., 1909: In Ewart, A.J., White, J. \& Rees, B.: Contributions to the flora of Australia No.11. Proc. R. Soc. Vict. n.s. 22: 6-28.

GrüNING, G., 1958: Euphorbiaceae - Porantheroideae et Ricinocarpoideae. Das Pflanzenreich 58: 21-25.

HookeR, J.D., 1847: Florae Tasmaniae Spicilegium, or contributions towards a Flora of Van Diemen's Land. Lond. J. Bot. 6: 283-284.

Hutchinson, J., 1969: Tribalism in the family Euphorbiaceae. Am. J. Bot. 56: 738-758.

MuELLER, F. VON, 1890: Descriptions of new Australian plants, with occasional other annotations. Vict. Nat. 7: 6668.

Orchard, A.E., 1988: A natural regions map for Tasmania. Pap. Proc. R. Soc. Tasm. 122: 47-51.

(accepted 2 February 1990)

A.E. Orchard

Tasmanian Herbarium, GPO Box 252C, Hobart, Tasmania, Australia 7001 